PEDAGOGISK FORSKNING I SVERIGE Vol 25 No 4 (2020) ISSN 1401-6788

\title{
Debatt
}

\section{Det tredje rummet som mötesplats}

\section{Lars Olsson}

Föreståndare för Forum för samverkan (FoSam), Uppsala universitet

Kontakt: lars.olsson@forumforsamverkan.uu.se

Anna Brunner Cederlund

Projektkoordinator vid Forum för samverkan (FoSam), Uppsala universitet Kontakt: anna.b.cederlund@forumforsamverkan

Den praktiknära forskningen rymmer många utmaningar. Vårt arbete som projektledare för Uppsala-noden inom försöksverksamheten ULF (Utveckling, lärande, forskning, U2015/03573/UH, U2017/01129/UH) har sedan starten 2017 gett oss kunskaper om samverkansmodeller på olika nivåer för att möjliggöra praktiknära forskning. Med avstamp i dessa erfarenheter vill vi argumentera för att den praktiknära forskningen behöver bedrivas inom ramen för varaktiga mötesplatser och forskningsmiljöer som är gemensamma för huvudmän och lärosäten. För att lägga grunden för jämbördiga möten mellan personer från förskola/skola och personer från lärosäten, liksom att skapa ömsesidigt berikande samverkan behövs miljöer som består över tid och aktivt griper in i verksamheterna. För att den praktiknära forskningen ska kunna stärkas är det därför centralt att resurser mobiliseras för dessa miljöer.

Försöksverksamheten ULF utvärderas löpande av en forskargrupp vid Universitetet i Sørøst-Norge (Prøitz m.fl., 2020). I sin delrapport 2 analyserar de försöksverksamheten utifrån begreppsbildningen "third space/det tredje rommet". Detta begrepp, menar vi, synliggör de mekanismer och funktioner som behöver vara på plats för att möjliggöra en praktiknära forskning som i förlängningen ger en forskningsbaserad kvalitetsutveckling i förskola och skola likväl som en förstärkt vetenskaplig grund i lärarutbildningarna. 
Utmärkande för det tredje rummet är att parterna möts jämbördigt: "likeverdige aktører med ulik kompetanse bringer ulike diskurser fra ulike kontekster til torgs i partnerskapene" (Prøitz m.fl., 2020, s.85). När begreppet här appliceras på skolans område tänker vi att aktörerna är dels skolans yrkesverksamma, primärt lärare och skolledare, dels forskare vid lärosäten inom utbildningsvetenskap eller andra för skolan relevanta ämnesområden. Dessa aktörer kommer då från det första rummet (skolverksamheterna) respektive det andra rummet (forskningen).

På den arena eller mötesplats som det tredje rummet utgör finns förutsättningar för aktörerna att skapa en gemensam diskurs och ett gemensamt språk. Detta förutsätter att de sammanstrålande kunskapsfälten ses som likvärdiga, att man möts i vad som ibland benämns "ögonhöjd". Prøitz m.fl. (2020) noterar att i det tredje rummet formas praktikens frågor till forskningsbara frågor; professionen (lärare och rektorer) involveras i forskningen och forskningsresultaten nyttiggörs i utvecklingsarbete. I förlängningen utvecklas den pedagogiska praktiken och forskningsresultaten har möjlighet att stärka lärarutbildningarna. Särskilt betonas huvudmännens roll i skapandet av ett tredje rum: "Betydningen av dobbeltkompetanse (i form av personer med både forsker- og lærerkompetanse/erfaring) hos huvudmannen synes å være en nøkkel i ULF samarbeidet" (Prøitz m.fl., 2020, s. 89).

Inom försöksverksamheten pågår många olika försök med att skapa dessa tredje rum. I ett flertal samarbeten mellan huvudmän och lärosäten prövas modeller för att utveckla gemensamma forskningsmiljöer. Det handlar framför allt om att organisera miljöer med utgångspunkt i de förutsättningar som finns i den lokala eller regionala kontexten. I några fall vidareutvecklas befintliga plattformar, medan det i andra fall sker försök med att skapa nya miljöer geografiskt och organisatoriskt placerade hos huvudmannen. Miljöerna ska säkerställa forskning av hög kvalitet som utgår från professionens frågor, involvera lärarstudenter samt skapa möjligheter för bred delaktighet och spridning bland förskollärare/lärare/skolledare. Vi ser behovet av att forskningsmiljöerna bärs upp av personer med dubbla kompetenser, det vill säga både har forskarerfarenhet och erfarenheter från undervisning och utvecklingsarbete inom förskola eller skola. Kommunlektorer och kommundoktorander kan utgöra exempel på dessa dubbla kompetenser men även forskare inom akademin med kombinationstjänster som delas mellan lärosäte och huvudman. Genom sina dubbla erfarenheter har dessa personer en viktig roll i formandet av det tredje rummets gemensamma diskurs.

Det framstår med all tydlighet att tid är en kritisk faktor när det tredje rummet ska etableras. Det tar tid att bygga tillit. Det tar tid att skapa ett gemensamt språk och en gemensam agenda. Det tar tid att forma lärares och skolledares frågor till forskningsbara frågor. Det tar (lång) tid att genomföra 
forskningsprojekt. Det tar tid att involvera lärarstudenter. Och det tar tid när erfarenheter och kunskaper från forskning ska spridas och användas i förskola och skola. Vi menar att forskningsmiljön har möjlighet att bli det tredje rum som är bestående över tid och där forskningsprojekten kan komma och gå.

Vår erfarenhet är att dessa miljöer kräver ett långsiktigt engagemang hos parterna vilket i sin tur pekar på behovet av avtal. Under försöksverksamheten har deltagande huvudmän och lärosäten lagt mycket tid på att formulera samarbetsavtal. De samtal som har lett fram till konkreta avtal har innefattat diskussioner såväl om önskvärda samverkansmodeller som om innebörder av begrepp som praktiknära forskning och vetenskaplig grund. Vi noterar att det finns starka kulturer och vanor i de olika organisationerna. För att skapa ett tredje rum där möten sker i ögonhöjd måste aktörerna vara beredda på att förändras. Ahrenfelt (2001) menar att det för att skapa beständig förändring krävs förändringar av andra ordningen, där det organisatoriska agerandet och tänkandet ändras kvalitativt hos de parter som deltar (s. 23). Först då blir det möjligt att förändra system på djupet med nya tankemönster och nya sätt att lösa problem. Över tid kan ett tredje rum medverka till att öppna upp mellan olika beslutsstrukturer och gamla hierarkier mellan den akademiska världen och skolpraktiken - en förändring av andra ordningen.

Vi iakttar här att det tredje rummet inbegriper en ytterligare nivå än själva forskningsmiljön (dvs. verkstaden där forskning pågår), nämligen den som utgörs av gemensamma beslutsstrukturer mellan huvudman och lärosäte. Även här är varaktigheten över tid helt avgörande för att på denna ledningsnivå skapa en gemensam agenda och samordnade prioriteringar. Kopplat till behovet av långsiktiga samverkansavtal (ULF-avtal) framträder behovet av en långsiktigt tryggad finansiering. De statliga ULF-medel som försöksverksamheten förfogar över har fungerat som en katalysator för att få till stånd fördjupade samarbeten och substantiell medfinansiering från både huvudmän och lärosäten. Det är vår övertygelse att en god, stabil finansiering borgar för långsiktighet och kvalitet. Ska den praktiknära forskningen stärkas behöver det finnas resurser inte bara för enskilda forskningsprojekt utan även för forskningsmiljöer. Om forskningsprojekt har en löptid på minst tre år så är behovet att säkerställa kontinuitet i forskningsmiljöer snarare tio år, kanske längre. Arbetet inom ULF-avtalen behöver få sjunga långsamhetens lov - där processen och vägen framåt är lika viktiga som färdiga resultat.

\section{REFERENSER}

Ahrenfelt, Bo (2001). Förändring som tillstånd. Lund: Studentlitteratur AB.

Prøitz, Tine S., Rye, Ellen M., Barstad, Kristin, Afdal, Hilde, Risan, Majken, \& Aasen, Petter (2020). Utbildning, lärande, forskning: En evalueringsstudie - delrapport 2. Skriftserien nr. 38, 2020. Horten: Universitetet i Sørøst-Norge. 